\title{
Research Paper Price stability of soybean for major markets of India
}

See end of the paper for authors' affiliations

Correspondence to :

\section{A.S. TINGRE}

Department of Agricultural Economics and Statistics,

Dr. Panjabrao Deshmukh Krishi Vidyapeeth, AKOLA (M.S.) INDIA

Paper History :

Received : 01.04.2016;

Revised : 16.07.2016;

Accepted : 14.08 .2016
Abstract : Soybean is the leading oilseed produced globally. Huge fluctuations in prices of farm produce are observed during past few years. The present study aimed to study price movement of soybean i.e. seasonal variations, price volatility and co-integration among the major soybean markets in India. For study purpose the data related to monthly average prices of soybean were collected from major markets of different states viz., Akola and Latur (Maharashtra), Kota (Rajasthan), Bailhongal (Karnataka) and Nizamabad (Andhra Pradesh) for the period 2001-2013. Moving average method was used to study seasonal variations. The econometric tools like ADF test, Johansen's multiple cointegration test, granger causality test and ARCH-GARCH model were used to arrive at conclusions. The results of study showed that the prices of soybean were higher in the months from June to August in all selected markets. For all selected markets the prices series are free from the consequences of unit root and were stationary at first difference. The selected markets show long run equilibrium relationship and co-integration between them. Most of the markets showed bidirectional influence on soybean prices of each other. Akola, Bailhongal, Kota and Latur market, recorded high price volatility in Soybean prices.

Key WordS : ADF test, ARCH- GARCH, Co-integration, Granger causality test, Price movement, Price volatility, Seasonal variation

How To Cite This PAPer : Tingre, A.S., Bhopale, A.A. and Deshmukh, R.G. (2016). Price stability of soybean for major markets of India. Internat. Res. J. Agric. Eco. \& Stat., 7 (2) : 169-174, DOI : 10.15740/HAS/IRJAES/ 7.2/169-174. 